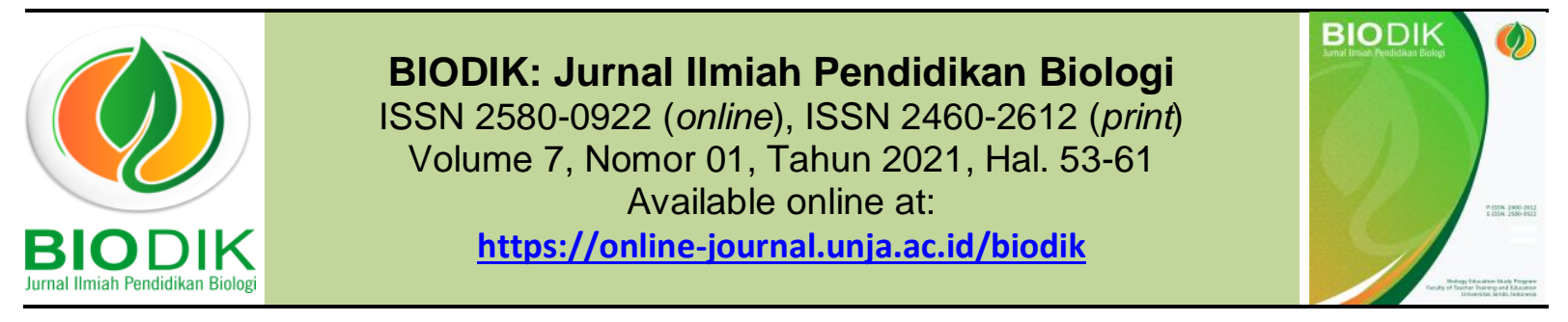

Research Article

\title{
Pengembangan Komik Biologi Pada Materi Pteridophyta Untuk Siswa SMA
}

\section{(Development of Biological Comics on Pteridophyta Material for High School Students)}

Karlena, Revis Asra, Bambang Hariyadi

Program Magister Pendidikan IPA Universitas Jambi

Jl. Raden Mattaher No.21, Ps. Jambi, Kota Jambi, Jambi 36133, Indonesia

Corresponding Authors: lenaunja2020@gmail.com

\begin{tabular}{|c|c|}
\hline Informasi Artikel & ABSTRACT \\
\hline $\begin{array}{l}\text { Submit: } 29-12-2020 \\
\text { Diterima: } 27-02-2021 \\
\text { Dipublikasikan: } 14-03-2021\end{array}$ & $\begin{array}{l}\text { This research is the background of the problems that occur in school, namely, lack of } \\
\text { interest in reading in students, students tend to choose subjects they like and student } \\
\text { learning outcomes are still low seen from their KKM scores. The research objective } \\
\text { was to develop comics on Pteridophyta material for class X SMA Negeri } 2 \text { Sungai } \\
\text { Penuh. The research method uses development research with the ADDIE model. The } \\
\text { stages include Analysis, Disgn, Development, Implementation and Evaluation. } \\
\text { Products in the form of comics are needed to attract students' interest in reading. } \\
\text { Products are validated by media experts and material experts. Validation by material } \\
\text { experts was carried out } 3 \text { (three) times, with a final percentage of } 80 \% \text { meaning that } \\
\text { the comic was in the valid category with a reasonable conclusion to be produced with } \\
\text { revisions according to the suggestions. Meanwhile, the validation by media experts } \\
\text { was carried out } 2 \text { (two) times by obtaining a percentage of } 88 \% \text {, meaning that the } \\
\text { comic was in the very valid category with the conclusion that it was feasible to be } \\
\text { produced with revisions according to the suggestions. The comic on Pteridophyta } \\
\text { material for high school class X students obtained practical feasibility in the very good } \\
\text { category. Practical feasibility was obtained from teachers and students in group trials. } \\
\text { Eligibility of the teacher with a percentage of } 88.24 \% \text {, small group trials with a } \\
\text { percentage of } 85.33 \% \text {, trials of two large groups with a percentage of } 84.67 \% \text { and } \\
84.08 \% \text { respectively. From the two large group trials, an agreement was obtained } \\
\text { that strong and significant enough regarding the feasibility of comics on Pteridophyta } \\
\text { material for class X high school students. Thus, the development carried out on } \\
\text { products in the form of comics on Pteridophyta material can be produced and used in } \\
\text { Biology learning in class X. } \\
\text { Keywords: Development, Comic, Pteridophyta }\end{array}$ \\
\hline Penerbit & ABSTRAK \\
\hline $\begin{array}{l}\text { Program Studi Pendidikan } \\
\text { Biologi, Fakultas Keguruan dan } \\
\text { Ilmu Pendidikan, Universitas } \\
\text { Jambi }\end{array}$ & $\begin{array}{l}\text { Penelitian ini melatar belakangi masalah yang terjadi disekolah diantaranya yaitu, } \\
\text { Kurangnya minat baca pada siswa, siswa cenderung memilih mata pelajaran yang } \\
\text { disukai dan hasil belajaar siswa yang masih rendah dilihat dari nilai KKM-nya. Tujuan } \\
\text { penelitian adalah untuk mengembangkan komik pada materi Pteridophyta untuk } \\
\text { siswa kelas X SMA Negeri } 2 \text { Sungai Penuh. Metode penelitian menggunakan } \\
\text { penelitian pengembangan dengan model ADDIE. Tahapan meliputi Analys, Disgn, } \\
\text { Development, Implementation dan Evaluation. Produk berupa komik dibutuhkan } \\
\text { untuk menarik minat baca siswa. Produk di validasi oleh ahli media dan ahli materi. } \\
\text { Validasi oleh ahli materi dilakukan sebanyak } 3 \text { (tiga) kali, dengan memperoleh } \\
\text { persentase akhir } 80 \% \text { artinya komik berada dalam kategori valid dengan } \\
\text { kesimpulan layak untuk diproduksi dengan revisi sesuai saran. Sedangkan } \\
\text { validasi oleh ahli media dilakukan } 2 \text { (dua) kali dengan memperoleh persentase } \\
88 \% \text {, artinya komik berada dalam kategori sangat valid dengan kesimpulan layak } \\
\text { untuk diproduksi dengan revisi sesuai saran. Komik pada materi Pteridophyta untuk } \\
\text { siswa SMA kelas X memperoleh kelayakan secara praktis dengan kategori }\end{array}$ \\
\hline
\end{tabular}


sangat baik. Kelayakan praktis diperoleh dari guru dan siswa pada uji coba kelompok. Kelayakan dari guru dengan persentase sebesar $88,24 \%$, ujicoba kelompok kecil dengan persentase $85,33 \%$, uji coba dua kelompok besar dengan masing-masing persentase $84,67 \%$ dan $84,08 \%$.Dari uji coba dua kelompok besar didapat kesepakatan yang cukup kuat dan signifikan mengenai kelayakan komik pada materi Pteridophyta untuk siswa SMA kelas X. Dengan demikian, pengembangan yang dilakukan pada produk berupa komik pada materi Pteridophyta dapat diproduksi dan digunakan dalam pembelajaran Biologi pada kelas $X$.

Kata Kunci: Pengembangan, Komik, Pteridophyta

This BIODIK : Jurnal IImiah Pendidikan Biologi is licensed under a CC BY-NC-SA (Creative Commons Attribution-ShareAlike 4.0 International License)

\section{PENDAHULUAN}

Pembelajaran Biologi merupakan salah satu bagian dari pembelajaran sains yang dipelajari mulai dari jenjang Sekolah Dasar sampai perguruan tinggi di Indonesia. Pada jenjang SMA pembelajaran Biologi bertujuan untuk menumbuh kembangkan sikap ilmiah, membentuk sikap positif terhadap objek ciptaan Tuhan dan menumbuh kembangkan sikap analisis terhadap alam semesta.

Biologi merupakan ilmu pengetahuan yang membahas berbagai macam kehidupan di alam. Kegiatan belajar dan mengajar ilmu Biologi dapat memberikan pengalaman belajar yang baik dan bermakna bagi peserta didik untuk tiap sub pokok bahasan materi Biologi yang akan diajarkan.

Pada mata pelajaran Biologi terdapat beberapa materi dan berbagai pokok bahasan dan sub pokok bahasan. Salah satu dari materi Biologi yaitu Tumbuhan (Plantae). Tumbuhan (Plantae) merupakan pelajaran Biologi di kelas X Sekolah SMA semester genap (semester II).

Tumbuhan adalah suatu organisme yang memanfaatkan cahaya matahari sebagai sumber energi dan menggunakannya untuk menghasilkan makanan yang dibutuhkan untuk tumbuh dan bertahan hidup. Sel-sel tumbuhan memiliki dinding luar yang kuat dan tersusun oleh suatu senyawa, yaitu selulose yang menjadikannya dinding-dinding itu padat. Tumbuhan berkembang biak dengan cara menurunkan pesan genetiknya pada semua keturunan yang bentuknya menyerupai mereka. Ada sekitar 275.000 sampai 300.000 spesies tumbuhan spesies-spesies baru terus ditemukan, terutama di wilayah-wilayah tropis dunia yang belum pernah dijelajahi (Safitri, 2016: 177-179).

IImu tumbuhan pada masa sekarang telah mengalami kemajuan, hingga bidang-bidang pengetahuan yang semula hanya merupakan cabang-cabang ilmu tumbuhan saja, sekarang ini telah menjadi ilmu yang berdiri sendiri, seperti Morfologi Tumbuhan dan Taksonomi Tumbuhan. Tumbuhan mempunyai fungsi yang sangat utama bagi kelangsungan hidup manusia. Tumbuhan merupakan produsen bagi kehidupan, penghasil makanan dan oksigen bagi lingkungan. Jika dunia hijau karena tumbuhan, maka selamatlah lingkungan dari kerusakan.

Pada materi tumbuhan dibagi menjadi 3, yaitu tumbuhan lumut (Bryophyta), tumbuhan paku (Pteridophyta) dan tumbuhan biji (Spermatophyta). Tumbuhan paku merupakan sekelompok tumbuhan dengan sistem pembuluh sejati, tapi tidak pernah menghasilkan biji. Materi tumbuhan paku (Pteridophyta) menjadi penting dan perlu disampaikan kepada siswa. Tumbuhan paku ini merupakan suatu devisi yang warganya telah jelas mempunyai kormus, artinya tubuhnya dengan nyata dapat dibedakan dalam tiga bagian pokok, yaitu akar, batang dan daun.

Melalui dunia pendidikan, diharapkan siswa dapat mengubah pola pikir dan perilaku terhadap tumbuh-tumbuhan. Misalnya sebagai siswa, mereka seharusnya tahu manfaat tumbuhan bagi kehidupan manusia. Dengan pengetahuan tersebut, siswa tidak akan menyia-nyiakan tumbuhtumbuhan, seperti menebang pohon di hutan, membakar hutan, dan lain sebagainya. Siswa akan lebih menjaga kelestarian tumbuhan. Menanam pohon adalah bentuk pedauli terhadap tumbuh-tumbuhan. Karena tidak ada satupun makhluk ciptaan tuhan yang tidak ada manfaatnya. 
Karena tumbuhan sangat berperan penting bagi kehidupan manusia, terlebih tumbuhan paku, maka ada baiknya siswa juga perlu mengetahui manfaat dari tumbuhan paku, baik bagi kehidupan manusia, maupun bagi alam sekitar. Tumbuhan paku (Pteridophyta) selain bermanfaat sebagai bahan makanan, juga bermanfaat untuk tanaman hias, obat-obatan serta sebagai pupuk hijau. Banyak sekali manfaat dari tumbuh-tumbuhan, terutama tumbuhan paku. Namun terkadang siswa tidak mengetahuinya dikarenakan mereka kurang membaca. Sehingga hal itulah yang menyebabkan hasil belajar siswa tidak sesuai dengan apa yang mereka harapkan.

Agar siswa tertarik untuk membaca buku pelajaran, maka ada baiknya buku pelajaran tersebut dikembangkan. Salah satu bentuk media pelajaran yang menarik minat baca siswa adalah komik. Untuk mengetahui keseriusan siswa dalam membaca serta mempelajari bahasan buku pelajaran yang berbentuk komik, maka diberikan angket analisis kebutuhan siswa kepada dua kelas sejumlah lebih dari 60 angket. 85\% siswa menjawab beberapa pertanyaan bahwa mereka mau membaca buku biologi yang berbentuk komik dengan pokok bahasan tumbuhan paku, serta mereka merasa perlu media/tambahan buku penunjang biologi yang berbentuk komik.

Penelitian penggunaan komik di dalam dunia pendidikan sebelumnya telah dilakukan oleh beberapa peneliti. Diantaranya penelitian yang dilakukan oleh Akbar (2015:750-754), yang menyatakan bahwa penggunaan media komik dapat menarik perhatian siswa, sehingga dapat menumbuhkan minat belajar siswa. Selanjutnya penelitian yang dilakukan oleh Wahyuningsih (2011:102-110), di dalam penelitiannya menjelaskan ada 3 manfaat dari penggunaan media komik. (1) media komik dapat membantu siswa dari kesulitan dalam mempelajari materi sistem saraf manusia yang banyak memiliki istilah-istilah ilmiah atau bahasa ilmiah. (2) komik dapat membuat siswa merasa tertarik dan berminat untuk membaca materi sistem saraf manusia, dan (3) penggunaan media komik mampu meningkatkan hasil belajar siswa. Selanjutnya dalam penelitian Novianti dan Syaichudin (2010:74-85), ditemukan bahwa media komik dalam pembelajaran dapat meningkatkan pemahaman siswa. Kemudian, Handayani (2010:482-490) mengungkapkan bahwa komik sebagai media dalam pe/mberian informasi dapat meningkatkan pengetahuan dan sikap siswa. Dimana dapat meningkatkan pengetahuan sebesar tiga kali dan sikap sebesar empat kali dibanding dengan media grafis lainnya (leaflet)

Penelitian di atas merupakan penelitian mengenai penggunaan media komik dalam pembelajaran ataupun sebagai media untuk menyampaikan informasi. Akan tetapi, sejauh ini belum dikembangkan komik yang berisi materi Pteridophyta. Pengembangan media komik pada materi Pteridophyta dilakukan karena kurangnya pengetahuan siswa mengenai ciri-ciri dan manfaat tumbuhan paku. Melalui materi Pteridophyta yang disajikan melalui komik, dimana penyajian komik dilengkapi dengan gambar atau ilustrasi, alur cerita serta penggunaan bahasa yang singkat dan jelas. Komik merupakan cerita bergambar ataupun ilustrasi yang dapat membuat siswa mengetahui alur cerita ataupun arah cerita yang disampaikan. Dimana dalam komik tersebut yang menjadi tokoh utamanya adalah tumbuhan paku itu sendiri. Penggunaan bahasa dalam komik sangat singkat, jelas dan menarik perhatian dan minat baca siswa.

\section{METODE PENELITIAN}

Penelitian ini merupakan penelitian dan pengembangan atau disebut dengan Research and Development ( $R$ \& D). Menurut Goll, Gall dan Borg, Research and Development (R \& D) dalam pendidikan adalah sebuah model pengembangan dimana temuan penelitian digunakan untuk merancang produk dan prosedur baru, yang kemudian secara sistematis diuji di lapangan, dievaluasi dan disempurnakan hingga produk memenuhi kriteria tertentu, yaitu efektivitas dan berkualitas (Putra, 2013:84). Penelitian ini mengembangkan suatu media berupa Komik sebagai media pembelajaran biologi, pada materi Pteridophyta untuk siswa kelas X SMA.

Dalam proses pengembangan komik tersebut, menggunakan model pengembangan ADDIE. Model ADDIE terdiri dari 5 tahapan kegiatan, yaitu Analysis (Analisis), Design (Rekabentuk), Development (Pembangunan), Implementation (Pelaksanaan), Evaluation (Penilaian). Yang menjadi 
dasar pertimbangan untuk pemilihan model ADDIE adalah karena sederhana dan bersifat sistematis. Adapun tahapan dari model ADDIE dapat dilihat pada Gambar 1.

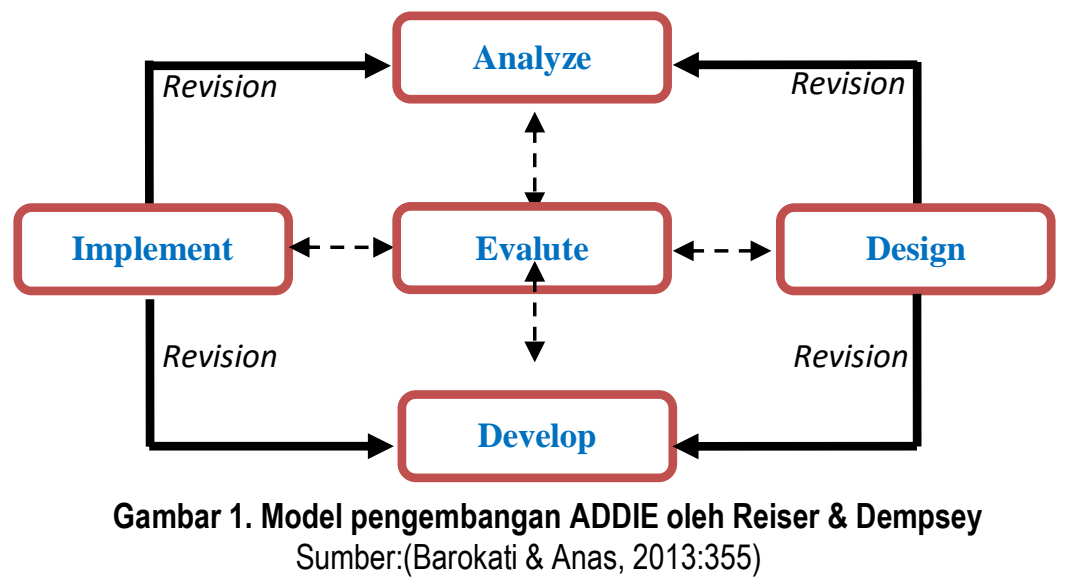

Dalam penelitian ini, instrumen yang digunakan adalah angket, wawancara dan observasi. Menurut Sugiyono (2014), "Angket merupakan teknik pengumpulan data yang dilakukan dengan cara memberi seperangkat pertanyaan atau pernyataan tertulis kepada responden untuk dijawabnya". Angket merupakan pengumpulan data yang dilakukan dengan cara memberi seperangkat pertanyaan atau penyataan tertulis kepada responden untuk dijawabnya (Sugiyono, 2012:142). Angket awal diberikan kepada guru Biologi dan siswa SMAN 2 Kota Sungai Penuh kelas X. Angket awal bertujuan untuk memperoleh informasi dan masalah-masalah dilapangan sehingga perlu dilakukannya suatu pengembangan media komik pada materi Ptetridophyta.

Angket awal guru terdiri dari 11 pertanyaan dengan bentuk esai. Sedangkan ada 2 angket awal siswa yang masing-masing terdiri dari 16 butir pertanyaan dengan skala Guttman. Skala Guttman merupakan skala yang menggunakan dua jawaban secara tegas dan konsisten, seperti: ya-tidak, benar-salah, pernah-tidak pernah, senang-tidak senang dan sebagainya (Iskandar, 2008:83). Angket validasi ahli menggunakan skala Likert. Skala Likert digunakan untuk mengukur sikap, pendapat, dan persepsi seseorang atau sekelompok orang tentang fenomena sosial. Dalam penelitian, fenomenan sosial ini telah ditetapkan secara spesifik oleh peneliti, yang selanjutnya disebut sebagai variabel penelitian. Dengan skala Likert, maka variabel yang akan diukur dijabarkan menjadi indikator variabel. Kemudian indikator tersebut dijadikan sebagai titik tolak untuk menyusun item-item instrumen yang dapat berupa pernyataan atau pertanyaan.

Skala Likert menggunakan beberapa item pertanyaan untuk mengukur perilaku seseorang dengan merespon 5 pilihan pada setiap item pertanyaan (sangat setuju, setuju, netral, tidak setuju, sangat tidak setuju) (Budiaji, 2013:128). Angket validasi diberikan kepada ahli materi dan ahli media. Hasil dari angket tersebut akan digunakan sebagai dasar dalam penentuan kualitas kelayakan materi dan media komik yang telah dibuat. Angket ahli materi berjumlah 15 pernyataan positif dan angket validasi ahli media berjumlah 20 pernyataan positif. Angket respon berisikan pernyataan berkaitan dengan media komik yang digunakan untuk mengetahui sejauh mana kepraktisan komik yang dikembangkan.

Tabel 1 Kategori tingkat validitas media pembelajaran komik oleh ahli materi

\begin{tabular}{ccccc}
\hline No & Skala Nilai & Skor & Persentase $(\%)$ & Kategori \\
\hline 1 & 5 & $63-75$ & $84-100$ & Sangat Valid \\
2 & 4 & $51-62,9$ & $68-83,87$ & Valid \\
3 & 3 & $39-50,9$ & $52-67,87$ & Cukup Valid \\
4 & 2 & $27-38,9$ & $36-5067$ & Tidak Valid \\
5 & 1 & $15-26,9$ & $20-35,87$ & Sangat Tidak Valid \\
\hline
\end{tabular}


Setelah memperoleh skor terendah, skor tertinggi dan mengetahui rentang nilai. Maka diperoleh tingkat validitas media komik menggunakan klasifikasi dengan ketentuan seperti pada Tabel 2.

Tabel 2 Kategori tingkat validitas media pembelajaran komik oleh ahli media

\begin{tabular}{|c|c|c|c|c|}
\hline No & Skala Nilai & Skor & Persentase $(\%)$ & Kategori \\
\hline 1 & 5 & $84-100$ & $84-100$ & Sangat Valid \\
\hline 2 & 4 & $68-83,9$ & $68-83,87$ & Valid \\
\hline 3 & 3 & $52-67,9$ & $52-67,87$ & Cukup Valid \\
\hline 4 & 2 & $36-51,9$ & $36-5067$ & Tidak Valid \\
\hline 5 & 1 & $20-35,9$ & $20-35,87$ & Sangat Tidak Valid \\
\hline
\end{tabular}

\section{HASIL PENELITIAN DAN PEMBAHASAN}

Hasil penelitian pengembangan ini merupakan sebuah media komik untuk siswa SMA kelas $X$ pada mata pelajaran Biologi materi Pteridophyta, Komik yang dikembangkan menggunakan model ADDIE. Adapun model pengembangan ADDIE terdiri dari 5 tahapan kegiatan, yaitu Analysis (Analisis), Design (Perancangan), Development (Pengembangan), Implementation (Implementasi), Evaluation (Evaluasi). Berikut adalah hasil pengembangan media komik yang telah diperoleh.

Tahap analisis bertujuan untuk mengumpulkan informasi atau data yang berkaitan dengan proses pembelajaran Biologi. Analisis kebutuhan dilakukan untuk menganalisis kebutuhan siswa, permasalahan belajar, silabus dan materi. Setelah melakukan analisis kebutuhan, selanjutnya dilakukan tahap desain komik Biologi pada materi Pteridophyta untuk digunakan peserta didik sebagai salah satu media dalam pembelajaran Biologi. Tahapan pengembangan merupakan tahapan untuk mewujudkan desain yang telah dirancang sedemikian rupa. Setelah produk berupa media komik telah selesai dibuat, maka produk siap untuk dilakukan validasi oleh dua orang ahli, yaitu ahli materi dan media.

Tahapan pengembangan merupakan tahapan untuk mewujudkan desain yang telah dirancang sedemikian rupa. Setelah produk berupa media komik telah selesai dibuat, maka produk siap untuk dilakukan validasi oleh dua orang ahli, yaitu ahli materi dan media. Setelah proses validasi selesai dan dilakukan ujicoba pada kelompok kecil, maka selanjutnya dilakukan ujicoba untuk mendapatkan informasi tentang keterpakaian media komik.

Tahap evaluasi selalu dilakukan pada setiap tahap pengembangan (evaluasi formatif) guna mengevaluasi proses setiap tahapan yang telah dilakukan, untuk menentukan langkah-langkah yang akan dilakukan selanjutnya.Selain evaluasi yang dilakukan disetiap tahapan pengembangan, dilakukan juga evaluasi sumatif terhadap produk yang dihasilkan yaitu media pembelajaran komik. Hasil ini menunjukan bahwa media pembelajaran komik yang dihasilkan dapat digunakan sebagai salah satu media alternatif pada pembelajaran Biologi, khususnya pada materi Pteridophyta.

Komik yang telah dikembangkan sebelumnya telah melalui validasi terlebih dahulu yaitu divalidasi oleh ahli materi dan ahli media sebelum diujicobakan kelapangan. Dimana hasil akhir dari produk media yang dikembangkan yaitu komik Biologi materi Pteridophyta. Validasi terhadap komik bertujuan untuk melihat kelayakan komik mulai dari desain cover, desain isi, kelayakan isi, penyajian, dan tata bahasa dalam komik. validasi dilakukan oleh dua validator yang terdiri dari validator ahli media dan validator ahli materi. Tahapan validitas ahli materi dapat dilihat pada Gambar 2. 


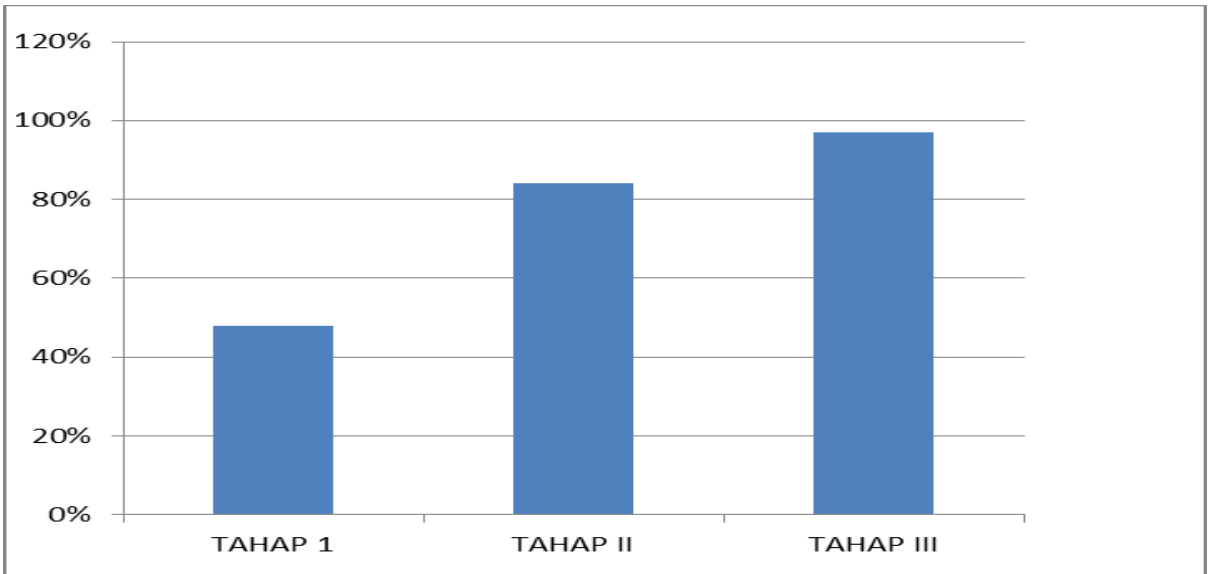

Gambar 1. Tahapan Validsi materi

Dari Gambar 1 diketahui validasi dari ahli materi dilakukan sebanyak tiga tahap, tahap pertama dengan kategori cukup valid, tahap kedua dengan kategori valid, dan tahap ketiga dengan kategori valid dan layak diujicobakan di lapangan. Berdasarkan validasi ahli materi produk yang dilakukan oleh ahli materi maka diperoleh hasil bahwa materi dalam komik Biologi pada materi Pteridophyta sudah memenuhi kriteria dan sesuai dengan kebutuhan peserta didik dan sesuai materi pembelajaran. komik yang dikembangkan sudah mengaitkan isi materi dengan kurikulum yang digunakan dalam pembelajaran Biologi, Bahasa yang digunakan dalam komik sangat sederhana, mudah dimengerti dan dipahami. komik juga menampilkan karakter tokoh yang unik, sehingga mendorong peserta didik lebih termotivasi untuk mempelajari materi pada Pteridophyta.

Komik yang dikembangkan sesuai dengan kompetensi dasar yang diambil dari kurikulum yang digunakan dan materi yang digunakan sesuai dengan kompetensi dasar, hal ini senada dengan pendapat Prastowo (2015), (1) kompetensi dasar yang tercantum dalam komik diambil dari pedoman khusus kurikulum, selanjutnya indikator keluasan materi yang disajikan mendukung pencapaian kompetensidasar (2) materi atau isi komik akan sangat bergantung pada kompetensi dasar yang akan dicapai, selanjutnya indikator ke dalaman materi yang disajikan sesuai dengan tingkat pendidikan peserta didik.

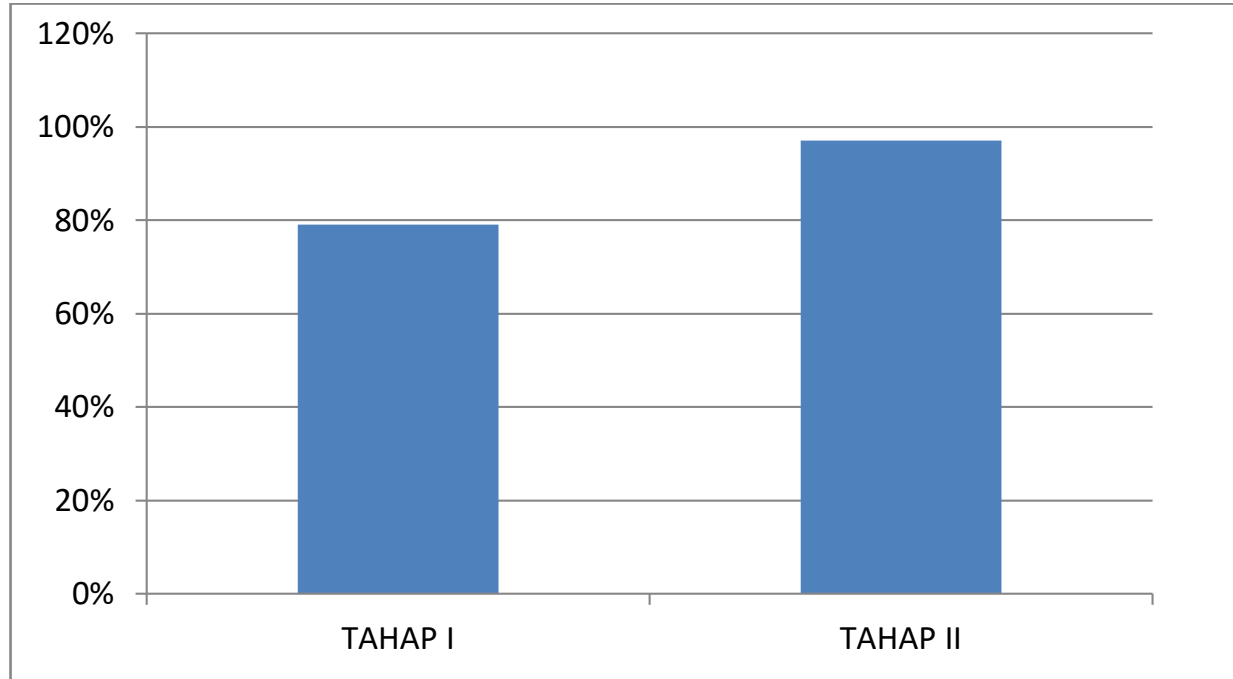

Gambar 3. Tahapan Validasi Media 
Berdasarkan Gambar 3 dapat diketahui validasi ahli media pada tahap pertama dengan kategori valid, maka perlu adanya perbaikan terhadap komik yang dikembangkan, pada tahap kedua dengan kategori Sangat valid, semua aspek sudah sesuai. Komik yang dikembangkan sudah sesuai dengan karakteristik peserta didik, dimana menurut Haryanto (2013:87) menjelaskan pada masa remaja 12-21, peserta didik sudah mempunyai kemandirian, tanggung jawab, keterampilan intelektual dan konsep membantu peserta didik dalam belajar. Berdasarkan hasil respon guru terhadap komik yang dikembangkan menunjukkan bahwa komik pada materi Pteridophyta memperoleh kategori sangat baik. Pada komik yang dikembangkan gaya penulisan sangat mudah dipahami peserta didik, hal ini sesuai dengan yang diungkapkan Prastowo (2015), yang mengatakan bahwa, gaya penulisan bahan ajar yang dikembangkan harus disesuaikan dengan materi dan kemampuan peserta didik.

Respon guru juga menunjukan sangat baik dalam hal ini gambar yang ditampilkan dalam komik yang dikembangkan sangat praktis, gambar-gambar yang ditampilkan dalam komik juga jelas dan menggunakan bahasa yang sederhana yang mudah dimengerti serta memiliki waktu yang lebih efisien. Untuk hasil respon siswa dapat dilihat pada Gambar 4.

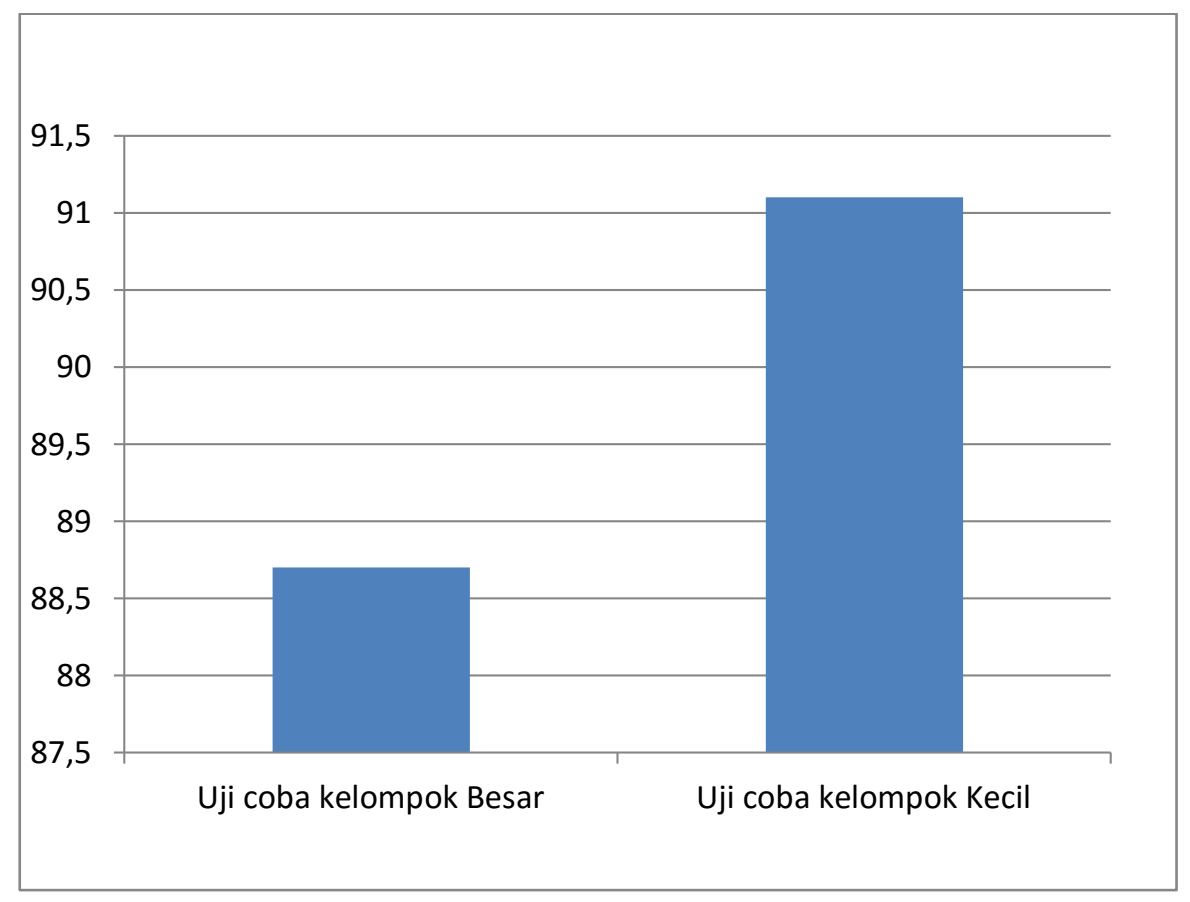

Gambar 4 hasil respon peserta didik

Berdasarkan gambar 4 respon siswa dalam hal ini uji coba kelompok kecil terhadap komik yang dikembangkan sangat baik dengan persentase $91 \%$ untuk uji coba kelompok kecil dan $87,5 \%$ uji coba kelompok besar. Komik yang disajikan memuat gambar-gambar yang unik dan menarik. Menurut Haka, N. B. (2020) komik dapat mempermudah pembelajaran biologi bagi peserta didik. Utariyanti, I. F. Z., Wahyuni, S., \& Zaenab, S. (2016) menambahkan bahwa komik dapat layak digunakan dalam pembelajaran biolgi.

\section{KESIMPULAN}

Kesimpulan dalam penelitian ini bahwa Media komik pada materi Pteridophyta untuk siswa SMA kelas $X$ dikembangkan dengan model ADDIE. Model ADDIE terdiri dari 5 tahapan kegiatan, pertama tahap analysis (analisis) dilakukan dengan melakukan observasi dan memberikan angket awal kepada guru dan siswa. Kedua, tahap design (perancangan) komik dirancang sedemikian rupa mulai dari tampilan komik, komponen/lembaran komik hingga proses pembuatan komik (terdiri dari: pembuatan alur cerita, penentuan tokoh dan karakter dan pengerjaan komik). Ketiga, 
tahap development (Pengembangan) menghasilkan media komik kemudian dilakukan validasi oleh dua orang ahli hingga dinyatakan layak dan diujjicobakan pada kelompok kecil. Keempat, tahap implementation (implementasi) dilakukan ujicoba pada guru dan dua kelompok besar. Kelima, tahap evaluation (evaluasi) dilakukan secara formatif dan sumatif. Media komik pada materi Pteridophyta untuk siswa SMA kelas X memperoleh kelayakan secara teoritis dari dua orang ahli, yaitu ahli materi dan ahli media. Validasi oleh ahli materi dilakukan sebanyak 3 (tiga) kali, dengan memperoleh persentase akhir $80 \%$ artinya komik berada dalam kategori valid dengan kesimpulan layak untuk diproduksi dengan revisi sesuai saran. Sedangkan validasi oleh ahli media dilakukan 2 (dua) kali dengan memperoleh persentase $88 \%$, artinya komik beradadalam kategori sangat valid dengan kesimpulan layak untuk diproduksi dengan revisi sesuai saran. Media komik pada materi Pteridophyta untuk siswa SMA kelas X memperoleh kelayakan kelayakan secara praktis dengan kategori sangat baik. Kelayakan praktis diperoleh dari guru dan siswa pada uji coba kelompok. Kelayakan dari guru dengan persentase sebesar $88,24 \%$, ujicoba kelompok kecil dengan persentase $85,33 \%$, uji coba dua kelompok besar dengan masing-masing persentase $84,67 \%$ dan $84,08 \%$.Dari uji coba dua kelompok besar didapat kesepakatan yang cukup kuat dan signifikan mengenai kelayakan media komik pada materi Pteridophyta untuk siswa SMA kelas $\mathrm{X}$.

\section{UCAPAN TERIMA KASIH}

Dalam proses penyusunan hingga terselesaikannya tesis ini tidak terlepas dari bimbingan, arahan dan bantuan dari berbagai pihak, untuk itu penulis mengucapkan terima kasih yang sebesarbesarnya terutama kepada yang terhormat Ibu Dr. Revis Asra, S.Si, M.Si selaku pembimbing I, Bapak Ir. Bambang Hariyadi, M.Si., Ph.D selaku pembimbing II dan sekaligus sebagai ketua Program Studi Magister Pendidikan IImu Pengetahuan Alam yang telah membimbing dan memotivasi penulis selama proses penyelesaian tesis ini. Tak lupa pula penulis mengucapkan terima kasih kepada yang terhormat: Rektor Universitas Jambi dan Direktur Program Pascasarjana Universitas Jambi. Bapak Prof. Dr. Aprizal Lukman, M.Pd selaku penguji I dan Bapak Dr. Nazaruddin, M.Si selaku penguji II. Ibu Dr. Yusnaidar, S.Si, M.Si selaku sekretaris program studi Magister Pendidikan Ilmu Pengetahuan Alam Universitas Jambi. Ibu Dr. Upik Yelianti, M.S selaku validator materi dan Ibu Dr. Wilda Syahri selaku validator media. Bapak dan Ibu dosen khususnya dosen program Studi Magister Pendidikan IImu Pengetahuan Alam yang telah banyak memberikan ilmu kepada penulis selama mengikuti pendidikan di Program Pascasarjana Universitas Jambi. Bapak Syahdanur Gusmin R, S.Pd, MM selaku kepala SMA N 2 Sungai Penuh yang telah memberikan izin untuk melakukan penelitian dan Ibu Novia Rahayu, S.Pd selaku guru Biologi dan responden di SMA Negeri 2 Sungai Penuh Siswa siswi kelas X MIA SMA Negeri 2 Sungai Penuh yang telah membantu sebagai responden dalam penyelesaian tesis ini. Kedua orang tua tercinta Ayahanda Ahmad Darwin dan ibunda Wardiah yang telah memberikan do'a, semangat, dukungan dan dari tetes keringat merekalah tesis ini dapat terselesaikan dengan baik. Teman-teman seperjuangan pada program magister pendidikan IPA Pascasarjana Universitas Jambi yang telah membantu dan memberikan dukungan dalam menyelesaikan tesis ini. Semua pihak yang tidak dapat penulis sebutkan satu per satu yang telah memberikan bantuan berupa moril dan materil kepada penulis. 


\section{DAFTAR PUSTAKA}

Akbar, OA. (2015). Minat Belajar Siswa terhadap Media Komik Berbasis Pendekatan Saintifik pada Materi Sistem Pencernaan Kelas XI SMA. BioEdu, 4 (1), 750-754.

Arahim, Z., dkk. (2009). IImu Pengetahuan Alam untuk SMP/MTs Kelas VII. Jakarta: Pusat Perbukuan, Departemen Pendidikan Nasional.Ariesta, O. (2013). Kebudayaan Lokal Sebagai Potensi dalam Berkarya Komik. Bercadik, 1 (1), 95-110.

Budiaji, W. (2013). Skala Pengukuran dan Jumlah Respon Skala Likert. Jurnal IImu Pertanian dan Perikanan [JIPP], 2 (2), 127-133.

Gumelar, MS. (2011). Cara Membuat Komik. Jakarta: PT. Indeks.

Handayani, S. (2010). Perbandingan Efektifitas Pemberian Informasi Melalui Media Cerita Bergambar (Komik) Versi BKKBN dengan Media Leaflet. Gaster, 7 (1), 482-490.

Haka, N. B. (2020). Pengembangan Komik Manga Biologi Berbasis Android untuk Peserta Didik Kelas XI Ditingkat SMA/MA. Journal of Biology Education, 1(1), 17-32. DOI: http://dx.doi.org/10.21043/jobe.v1i1.3284

Iskandar. (2008). Metodelogi Penelitian Pendidikan dan Sosial (Kuantitaif dan Kualitatif). Jakarta: Gaung Persada Press.

Manalu, MA. (2017). Pengembangan Media Komik Matematika Berbasis Nilai Karakter pada Materi Trigonometri Di Kelas X SMA Negeri 1 Indralaya Utara. Jurnal Elemen, 3 (1), 35-48.

Mukti, DN. (2015). Penciptaan Karya Komik Alternatif. Jurnal Pendidikan Seni Rupa, 3 (2), 1622.118

Mulyani, SP. (2015). Pengembangan Media Komik untuk Pembelajaran Bahasa Jawa di Kelas III SD Negeri Tegalpanggung. Skripsi. Yogyakarta: Universitas Negeri Yogyakarta.

Novianti, RD dan Syaichudin, M. (2010). Pengembangan Media Komik Pembelajaran Matematika untuk Meningkatkan Pemahaman Bentuk soal Cerita Bab Pecahan Pada Siswa Kelas V SDN Ngembung. Jurnal Teknologi Pendidikan, 10 (1), 74-85.

Nurlatipah, N. (2015). Pengembangan Media Pembelajaran Komik Sains yang Disertai Foto untuk Meningkatkan Hasil Belajar Siswa Kelas VII SMP Negeri 2 Sumber pada Pokok Bahasan Ekosistem. Scientiae Educatia, 5 (2), 1-13.

Octaviany, I. (2013). Pengembangan Media Komik dengan Menggunakan Adobe Flash CS3 Professional untuk Mengajarkan Keterampilan Menulis Dongeng pada Siswa Kelas IX SMP Negeri 1 Sawangan. Skripsi. Yogyakarta: Universitas Negeri Yogyakarta.

Putra, N. (2013). Research dan Development Penelitian dan Pengembangan. Jakarta: PT. Raja Grafindo Persada.

Safitri, R. (2016). Biologi Peminatan Matematika dan IImu-ilmu Alam untuk SMA/MA X. Surakarta: CV Mediatama.

Sugiyono. (2017). Metode Penelitian Kuantitatif Kualitatif Dan R \& D. Bandung: Alfabeta CV.

Utariyanti, I. F. Z., Wahyuni, S., \& Zaenab, S. (2016). Pengembangan media pembelajaran berbasis komik dalam materi sistem pernapasan pada siswa kelas VIII MTs Muhammadiyah 1 Malang. JPBI (Jurnal Pendidikan Biologi Indonesia), 1(3). DOI: https://doi.org/10.22219/jpbi.v1i3.2668

Wahyuningsih, AN. (2011). Pengembangan Media Komik Bergambar Materi Sistem Saraf untuk Pembelajaran yang Menggunakan Strategi PQ4R. PP, 1 (2), 102-110. 